\title{
IMPLEMENTASI ISBAT NIKAH MASSAL DI MADURA: KAJIAN SOSIOLOGIS-FILOSOFIS
}

\author{
Muh. Fathoni Hasyim \\ Universitas Islam Negeri Sunan Ampel Jl. A. Yani 117 Surabaya. \\ E-mail: fathoni.hasyim@uinsby.ac.id
}

\begin{abstract}
Marriage is a very important and sacred event in married life. Marriage is a legitimate starting point to establish kinship and brotherhood of the two extended families. So, it's not uncommon for a wedding to be enlivened by a lively party, spending a very large budget. Nevertheless, there is a certain community in Madura that ignores it, so it does not record it in the official institution, the KUA (the Office of Religious Affairs). Even though marriage registration brings benefit, justice and protection of civil rights as well as preventive measures in preventing unawareness, so that the MWCNU of Gapura, Sumenep runs a program called "Mass Isbat Nikab". The above problems raise two questions. Why do many isbat of marriage occur in a married couple? and how is the implementation? The review of this article will focus on bow the implementation of mass marital marriage in Madura with socio-philosophical analysis.
\end{abstract}

Keywords: Marriage registration, marriage isbat, Madura

\begin{abstract}
Abstrak: Pernikahan adalah peristiwa yang sangat penting dan sakral dalam kehidupan berumah tangga. Dari pernikahan itulah awal mula terjalinnya hubungan kekerabatan dan persaudaraan dua keluarga besar secara sah. Sehingga tidak jarang sebuah pernikahan dimeriahkan dengan pesta yang meriah, sehingga menghabiskan budget yang sangat besar. Meskipun demikian terdapat sebuah komunitas tertentu di Madura yang mengabaikannya, sehingga salah satu cara adalah dengan tidak mencatatkannya pada institusi resmi yaitu KUA. Padahal pencatatan pernikahan mendatangkan kemaslahatan, keadilan dan perlindungan terhadap hak-hak perdata serta sebagai tindakan preventif dalam mencegah kemadaratan, sehingga kondisi ini yang mendasari program kerja MWC NU di Kecamatan Gapura Kabupaten Sumenep untuk mengadakan "Isbat Nikah Massal". Problematika di atas memunculkan dua pertanyaan yaitu Mengapa banyak terjadi isbat nikah pasangan suami istri di Madura serta bagaimana implementasinya? Kajian artikel ini akan difokuskan pada bagaimana implementasi isbat nikah massal di Madura dengan analisis sosio-filosofis .
\end{abstract}

Kata kunci: pencatatan perkawinan, isbat nikah, Madura

\section{Pendahuluan}

Tujuan pencatatan perkawinan adalah untuk mewujudkan ketertiban perkawinan di tengah masyarakat. Ini merupakan suatu 
upaya yang diatur melalui perundang-undangan, untuk melindungi martabat dan kesucian perkawinan, terutama untuk melindungi hakhak perempuan dalam kehidupan rumah tangga. Melalui pencatatan perkawinan yang dibuktikan dengan akta nikah, dan salinannya diberikan pada masing-masing suami isteri. masing-masing pasangan harus memiliki salinannya karena untuk langkah antisipasi apabila terjadi perselisihan atau percekcokan di antara mereka, atau salah satu tidak bertanggung jawab, maka yang lain dapat melakukan upaya hukum guna mempertahankan atau memperoleh hak-hak nya masing-masing.1

Diskursus pencatatan perkawinan adalah masalah yang sangat urgen, karena untuk menjaga agar tidak terjadi kesemerawutan perkawinan bagi masyarakat Indonesia khususnya yang beragama Islam. Disamping itu, semua yang terkait dengan tata cara perkawinan membutuhkan pencatatan, oleh karena itu perlu diatur dalam undang-undang perkawinan. Kompilasi hukum Islam menyatakan pada pasal 5 ayat (1) agar terjamin ketertiban perkawinan bagi masyarakat Islam, setiap perkawinan harus dicatat. Selanjutnya, pada ayat (2) pencatatan perkawinan tersebut pada ayat (1) dilakukan oleh pegawai pencatat nikah sebagaimana yang diatur dalam undang-undang No. 22 tahun 1946 jo. Undang-undang No. 32 tahun 1954.2 Dasar hukum yang menjadi pijakan keharusan mencatatkan perkawinan dan petugas pencatat perkawinan yang sah, jelas dan kokoh, tetapi masih diperlukan penjelasan lebih lanjut.

Hukum positif di Indonesia mengatur ketentuan-ketentuan hukum tentang pencatatan perkawinan yang dipahami sebagai syarat administratif. Artinya perkawinan tetap sah, karena standar sah dan tidaknya perkawinan ditentukan oleh norma-norma agama dari pihak-pihak yang melangsungkan perkawinan. Pencatatan menjadi penting karena merupakan syarat administratif yang bisa menjadikan suatu perkawinan mempunyai kekuatan hukum. Artinya jika perkawinan tidak dicatatkan, maka perkawinan tersebut tidak mempunyai kekuatan secara hukum. Akibat yang timbul adalah,

1Ahmad Rofiq, Hukum Islam di Indonesia (Jakarta: Raja Grafindo Persada, 1997), 107.

2Amiur Nuruddin dan Azhari Akmal Tarigan, Hukum Perdata Islam di Indonesia (Jakarta: Kencana Prenada Media Group, 2004), 123. 
apabila salah satu pihak melalaikan kewajibannya, maka pihak lain tidak dapat melakukan upaya hukum, karena tidak memiliki buktibukti yang sah dan otentik dari perkawinan yang dilangsungkannya. Keadaan seperti ini bertentangan dengan misi dan tujuan perkawinan itu sendiri.3 Pencatatan perkawinan melindungi kedua belah pihak agar mempunyai status hukum yang jelas dan kuat, serta mengantisipasi berbagai kemungkinan yang negatif dalam kehidupan berumah tanggga.

Selanjutnya menurut pasal 7 ayat (1) Kompilasi Hukum Islam menyatakan perkawinan hanya dapat dibuktikan dengan akta nikah yang dibuat oleh pegawai pencatat nikah. Dengan ini, dapat dikatakan bahwa akta nikah merupakan satu-satunya alat bukti perkawinan, dan bagi orang-orang yang tidak mencatatkan perkawinannya, maka segala akibat hukum yang terkait dengan peristiwa perkawinan tidak dapat diselesaikan melalui jalur hukum seperti perceraian ke pengadilan, pembagian harta bersama, pembagian warisan, dan status anak.4 Uraian di atas menunjukkan dampak negatif dari pengabaian pencatatan perkawinan. Bagi pasangan yang tidak mencatatkan perkawinannya yang dibuktikan dengan akta nikah, maka akan kesulitan bahkan ditolak, manakala mengajukan permohonan penyelesaian hukum di pengadilan agama. Namun bagi pasangan suami istri dengan alasan tertentu, sehingga belum memiliki akta nikah, diberikan solusi sebagai berikut:

1. Pasangan suami isteri yang karena sesuatu hal perkawinannya tidak dibuktikan dengan akta nikah, kompilasi membuka kesempatan kepada mereka untuk mengajukan permohonan isbat nikah (penetapan) kepada pengadilan agama. Isbat nikah merupakan proses penetapan pernikahan dua orang suami isteri, tujuan dari isbat nikah adalah untuk mendapatkan akta nikah sebagai bukti sahnya perkawinan sesuai dengan peraturan perundang-undangan yang berlaku di Indonesia. Hal ini

3Rofiq, Hukum Islam, 110.

4Faizah Bafadhal, "Isbat Nikah dan Implikasinya Terhadap Status Perkawinan Menurut Peraturan Perundang-Undangan Indonesia", Jurnal Ilmu Hukum, (Maret 2014), 3. 
dimaksudkan untuk membantu masyarakat agar di dalam melangsungkan perkawinan tidak hanya mementingkan aspekaspek hukum fikih saja, tetapi aspek-aspek keperdataannya juga perlu diperhatikan.5

2. Dalam pasal 7 ayat (2) dan (3) KHI disebutkan: (2) dalam hal perkawinan tidak dapat dibuktikan dengan akta nikah, dapat diajukan isbat nikahnya ke pengadilan agama. Ayat (3) isbat nikah yang dapat diajukan ke pengadilan agama terbatas mengenai halhal yang berkenaan dengan: Pertama, adanya perkawinan dalam rangka penyelesaian perceraian. Kedua, hilangnya akta nikah. Ketiga, adanya keraguan tentang sah atau tidaknya salah satu syarat perkawinan. Keempat, adanya perkawinan yang terjadi sebelum berlakunya undang-undang No.1 tahun 1974. Kelima, perkawinan yang dilakukan oleh mereka yang tidak mempunyai halangan perkawinan menurut undang-undang No.1 tahun 1974.

Berbicara mengenai isbat nikah bisa kita lihat di salah satu pulau di Jawa Timur, yaitu Madura. Madura adalah sebuah pulau yang terletak di sebelah timur laut Jawa Timur, terdiri dari empat kabupaten; Bangkalan, Sampang, Pamekasan dan Sumenep. Di samping itu terdapat pulau-pulau kecil di sekitarnya, seperti Sapudi, Kangean, Masalembu dan lain-lainnya. Jumlah penduduk pulau Madura lebih dari 3.854.595.6 Masyarakat Madura dikenal sebagai masyarakat yang religius, sangat taat kepada guru atau kiai, sehingga peristiwa peristiwa penting dan bersejarah selalu dikonsultasikan atau menghadirkan kiai, termasuk masalah perkawinan. Perkawinan dipandang kurang mendapat berkah kalau yang mengakadkan bukan ustaz atau kiainya. Hanya saja ketaatan beragama yang ditimbulkan dengan ketaatan pada kiai, kurang diimbangi dengan ketaatan pada hukum positif, sehingga banyak terjadi nikah siri (unregistered marriages) di beberapa tempat di pulau ini. Sehingga MWC NU Kecamatan Gapura Kab.Sumenep menginisiasi program isbat nikah massal, dan ternyata mendapat respon masyarakat secara luas.

5 Ibid., 117.

6 Statistik BPS Th. 2017 
Sejatinya, kajian tentang isbat nikah sudah banyak dilakukan oleh para peneliti dengan berbagai pendekatan, salah satunya dengan pendekatan yuridis.7 Sementara isbat nikah dengan pendekatan normatif telah dilakukan oleh Mieta Djohan OE dalam artikelnya yang dipublikasikan pada Jurnal Pranata Hukum.8 Hal yang sama juga dilakukan oleh Ramdani Wahyu Sururie. Dalam artikel Sururie dijelaskan bahwa hakikat isbat nikah adalah penetapan dan berfungsi secara administratif untuk memberikan perlindungan hukum dan kepastian hukum kepada pihak yang berakad perkawinan.9 Kajian penolakan isbat nikah bagi suami yang berpoligami perspektif maqasid syariah dikaji oleh Mohammad Roqib.10 Adapun kajian isbat nikah dengan pendekatan sosiologis-filosofis masih jarang dilakukan oleh para akademisi.

Dalam konteks inilah, artikel ini membahas tentang Implementasi isbat nikah massal yang diinisiasi oleh Ormas Islam Nahdlatul Ulama di Kecamatan Gapura Kab. Sumenep dengan pendekatan sosiologis-filosofis. Ada dua pertanyaan mendasar dalam kajian ini: Pertama, bagaimana setting sosial masyarakat Madura yang antusias mengikuti program isbat nikah massal? Kedua, bagaimana tinjauan sosiologis-filosofis terhadap fenomana isbat nikah tersebut? Kajian artikel ini akan difokuskan pada bagaimana implementasi isbat nikah massal di Madura dengan analisis sosiofilosofis.

\section{Isbat Nikah dan Setting Sosial di Madura}

7 Tentang kajian ini, dapat dikaji pada artikel yang ditulis Riswan Munthe dan Sri Hidayani, "Kajian Yuridis Permohonan Itsbat Nikah Pada Pengadilan Agama Medan, Jurnal Pendidikan Ilmu-Ilmu Sosial, Vol. 9. No. 2 (2017), 121-132.

8Lihat, Mieta Djohan Oe, "Isbat Nikah dalam Hukum Islam dan PerundangUndangan di Indonesia, Jurnal Pranata Hukum, Vol. 8 No. 2 (Juli 2013), 137-147. 9Ramdani Wahyu Sururie, Polemik di Seputar Isbat Nikah dalam Sistem Hukum Perkawinan Indonesia, al-Manabij: Jurnal Kajian Hukum Islam, Vol. XI No. 2 (Desember 2017), 233.

10Kesimpulan Rokib dalam kajiannya menunjukkan bahwa pertimbangan hakim dalam penolakan isbat nikah siri bagi suami yang sudah beristri adalah pertimbangan yuridis an-sich dan tidak mempertimbangkan aspek maqasid syariah. Lihat, Mohammad Rokib, "Penolakan Ithbat Nikah Siri Bagi Suami yang Sudah Beristri, Al-Hukama: The Indonesian Journal of Islamic Family Law, Vol. 06 No. 02 (Desember 2016), 243. 
Masyarakat Madura terkenal dengan tingkat kereligiusan yang tinggi. Etnik Madura sebagai bagian dari keberagamaan masyarakat muslim Indonesia yang sangat kuat menjaga tradisi dan budayanya. Hal ini karena etnik Madura memiliki interaksi dengan kompleksitas elemen-elemen sosio-kultural yang melingkupinya, sehingga menampakkan karakteristik keberislaman yang unik dan khas dilihat dari berbagai aspek kehidupannya. Misalnya, aspek keberdayaan ekonominya, orientasi pendidikannya hingga perilaku politiknya.11

Karakteristik masyarakat Madura yang khas dan unik inilah menjadikan Madura memiliki kehususan kultural yang tidak dimiliki oleh etnografi entitas komunitas etnik lain. Masyarakat Madura secara kultural memiliki tingkat ketaatan, ketundukan, dan kepasrahan secara hierarkis kepada figur-figur utama dalam berkehidupan praksis keberagamaan. Ada empat komponen utama di Madura yang dianggap sebagai figur di tengah masyarakat Madura. Keempat figur tersebut adalah Buppa,'Babbu, Guru, ban Rato (Ayah, Ibu, Guru, dan Pemimpin pemerintahan). Kepatuhan secara hierarkis kepada empat figur tersebut selalu mewujud dalam kehidupan sosial budayanya.12

Keniscayaan kepatuahan secara hierarkis kepada figur-figur di atas diaktualisasikan dalam praksis kehidupan sosial masyarakat sebagai “aturan normatif" yang mengikat satu sama lain. Oleh karena itu, pengabaian dan pelanggaran atas aturan yang mengikat secara normatif akan menyebabkan pelakukanya mendapatkan sanksi sosial maupun kultural. Pada tataran ini, masyarakat Madura sangat memegang teguh aktualisasi kepatuhan kepada figur-figur yang telah memberikan kontribusi kepada dirinya secara individu maupun kelompok sosial lainnya.13

11Taufiqurrahman, Islam dan Budaya Madura, (Makalah di presentasi pada forum Annual Conference on Contemporary Islamic Studies, Direktorat Pendidikan Tinggi Islam, Ditjen Pendidikan Islam, Departemen Agama RI, di Grand Hotel Lembang Bandung, 26-30 November 2006).

12A. Latief Wiyata, Madura yang Patub?; Kajian Antropologi Mengenai Budaya madura. Jakarta: CERIC-FISIP UI, 2003), 1.

13Taufiqurrahman, Islam dan Budaya Madura, (Makalah di presentasi pada forum Annual Conference on Contemporary Islamic Studies, Direktorat Pendidikan Tinggi Islam, Ditjen Pendidikan Islam, Departemen Agama RI, di Grand Hotel Lembang Bandung, 26-30 November 2006). 
Selain kepatuhan kepada orang tua, masyarakat Madura sangat patuh kepada figur guru. Penggunaan dan penyebutan istilah guru menunjuk dan menekankan pada pengertian Kiai-pengasuh pondok pesantren atau sekurang-kurangnya Ustaz pada "sekolah-sekolah" keagamaan. Peran dan fungsi guru lebih ditekankan pada konteks moralitas yang dipertalikan dengan kehidupan eskatologis -terutama dalam aspek ketenteraman dan penyelamatan diri dari beban atau derita di alam kehidupan akhirat (morality and sacred world). Oleh karena itu, ketaatan orang-orang Madura kepada figur guru menjadi penanda khas budaya mereka yang tidak perlu diragukan lagi keabsahannya.

Kepatuhan kultural orang Madura kepada Guru (Kiai/Ustaz) maupun kepada pemimpin pemerintahan karena peran dan jasa mereka itu dipandang bermanfaat dan bermakna bagi survivalitas entitas etnik Madura. Guru berjasa dalam mencerahkan pola pikir dan perilaku komunal murid, untuk memperoleh kesejahteraan hidup di dunia dan keselamatan di akhirat kelak. Kontribusi mereka dipandang sangat bermakna dan berjasa besar, karena telah memberi bekal untuk survivalitas hidup di alam dunia dan keselamatan di akhirat pasca kehidupan dunia.

Dalam konteks inilah, salah satu alasan digagasnya program isbat nikah massal di Kecamatan Gapura Kabupaten Sumenep, karena banyaknya masyarakat melakukan pernikahan siri atau tidak didaftarkan kepada Pejabat Pencatat Nikah (PPN) sebagaimana yang telah ditentukan dalam Undang-Undang. Nikah siri di beberapa komunitas Madura menjadi hal yang biasa dilakukan, bahkan bisa menjadi tradisi tanpa mereka berfikir tentang peraturan Negara yang mengatur ketentuan pencatatan perkawinan. 14

Akad pernikahan antara kedua mempelai yang diakadkan oleh Kiai, biasanya dilakukan berdasarkan ketentuan-ketentuan agama Islam. Artinya, syarat-syarat hukum pernikahan Islam sudah terpenuhi, sehingga secara hukum Islam pernikahan tersebut sudah diklaim sah secara hukum agama. Pemahaman fikih semacam ini, karena memahami fikih secara tradisional sehingga baginya pencatatan pernikahan tidak menjadi aspek penentuan sah tidaknya

14Khoiriyah, Wawancara, 29 Maret 2019. 
suatu akad pernikahan. Oleh karena itu, masyarakat banyak melakukan pernikahan tanpa pencatatan perkawinan di Kantor Urusan Agama (KUA).

Sebagian besar masyarakat di Kecamatan Gapura saat menikah langsung melalui Kyai. Fenomena ini karena memang sudah biasa terjadi juga dalam rangka untuk mendapatkan "berkah" dari Kiai tersebut. Masyarakat di daerah Kecamatan Gapura sendiri memang kawasan pondok pesantren, sehingga kepatuhan terhadap ajaran agama mereka sangat kuat dan tingkat religiusitasnya sangat tinggi.

Hasil wawancara dengan ibu Armiatun (47 Tahun) salah satu penduduk daerah Gapura Barat menunjukkan bahwa ia menceritakan pernikahannya dahulu diakadkan oleh Kiai di daerah setempat. Hal itu, karena perintah dari orang tua dan kedua pihak menuruti apa yang dikatakan orang tua mereka.15 Informan lain dari Masida (43 Tahun) dari daerah Gapura Timur beliau juga mengakui hal yang sama bahwa pernikahan beliau juga diakadkan oleh Kiai dari daerah setempat. Alasannya, karena dari dulu memang kebiasaan Kiai yang menikahkan dan mengakadkan pernikahan.16

Selain itu, sebagian besar masyarakat Kecamatan Gapura saat ingin melangsungkan pernikahan selalu mewakilkan langsung kepada Kepala Desa selaku aparat yang mengetahui peraturan dan administrasi pemerintah tentang pernikahan. Kemudian Kepala desa tersebut dibantu oleh Modin yang bertugas dalam bidang keagamaan masyarakat memfasilitasi masalah pernikahan dan perceraian.

Ironisnya, kebanyakan dari mereka tidak menindak lanjuti hal ini, sehingga pernikahan yang berlangsung di kalangan masyarakat Kecamatan Gapura tidak dicatatkan di KUA setempat sebagaimana yang diatur dalam peraturan perundang-undangan. Dengan demikian, pernikahan tersebut tidak memiliki akta nikah dan tidak memiliki kekuatan hukum positif yang mengharuskan adanya pencatatan dalam setiap akad pernikahan.17

\section{Ormas Islam dan Program Isbat Nikah Massal}

15Armiatun, Wawancara, 2 April 2019.

16Masida, Wawancara, 2 April 2019.

17Fithratul Qayyimah, Wawancara, 1 April 2019. 
Program isbat nikah massal di Kecamatan Gapura Kabupaten Sumenep digagas oleh Majelis Wakil Cabang Nahdlatul Ulama (MWC NU). Program ini dilaksanakan di gedung aula lantai lantai II MWC NU Kecamatan Gapura. Gagasan ini berawal dari upaya sosialisasi kepada masyarakat tentang Undang-Undang Perkawinan kepada masyarakat dari perspektif hukum agama dan hukum negara (Hukum Positif).

Bidang hukum, politik, advokasi dan pendidikan MWC NU Kec. Gapura Kab. Sumenep menyadari bahwa tanpa adanya tindaklanjut dari upaya sosialisasi tentang pentingnya pencatatan perkawinan bagi masyarakat, maka hal tersebut tidak memberikan dampak signifikan bagi masyarakat luas. Oleh karena itu, mempertimbangkan banyaknya masyarakat yang pernikahannya belum dicatatkan dan tidak memiliki buku nikah dari pernikahan tersebut, maka kemudian mereka sepakat untuk menginisiasi kegiatan isbat nikah massal gratis.

Selanjutnya, pengurus MWC NU Kecamatan Gapura melakukan survei dan mendata setiap kepala keluarga yang tidak memiliki buku nikah di Kecamatan Gapura. Setelah selesai pendataan masyarakat yang tidak memiliki buku nikah, kemudian pengurus MWC NU mengumpulkan syarat-syarat yang diperlukan guna memenuhi persyaratan isbat nikah sebagaimana mestinya.

Awalnya, pihak MWC NU Kecamatan Gapura menggagas kerjasama dengan Pengadilan Agama Kabupaten Sumenep untuk menyelenggarakan kegaiatan isbat nikah massal secara gratis. Sayangnya, pihak pengadilan Agama setempat tidak memiliki kesepahaman sehingga program tersebut tidak dapat dilakasakan. MWC Nahdlatul Ulama Kecamatan Gapura akhirnya menjalin kerjasama dengan bidang hukum pemerintah daerah Kabupaten Sumenep. Hal ini karena Pemkab Kabupaten Sumenep memiliki program yang sama dengan MWC NU, yakni penyelenggaraan kegiatan isbat nikah gratis bagi masyarakat yang tergolong dari ekonomi yang kurang mampu. Dengan demikian, kegiatan isbat nikah massal sebagian besar dibiayai oleh bidang hukum pemerintah daerah Kabupaten Sumenep dengan kuota maksimal 200 pasangan. Akan tetapi, kuota tersebut hanya terpenuhi 160 pasangan. 
Pasangan yang mengikuti isbat nikah massal hanya dipungut biaya administrasi untuk kelengkapan berkas sebesar Rp. 50.000,kepada panitia pelaksana. Dengan rincian, biaya tersebut untuk membayar transportasi, foto kopi berkas-berkas dan materai untuk dilegalisir di Kantor Pos. Peserta yang mengikuti kegiatan isbat nikah massal ini terdiri atas masyarakat yang tinggal di beberapa desa yang berada di Kecamatan Gapura dan tercatat ada 160 pasangan.18

Sejatinya, tujuan program isbat nikah massal oleh MWC NU Kecamatan Gapura adalah: pertama, untuk meningkatkan kesadaran masyarakat akan pentingnya hukum negara. Kedua, membantu masyarakat yang tidak mampu dalam memperoleh akta perkawinan, yang dilakukan dengan sederhana, cepat dan biaya ringan.

Adapun pelaksanaan isbat nikah massal tersebut sama dengan pelaksanaan isbat nikah yang dilakukan di Pengadilan Agama. Akan tetapi, yang membedakan adalah dari sisi pelaksanaannya yang bertempat di luar pengadilan dan dilakukan secara gratis dengan menghadirkan hakimnya ke tempat pelaksanaan isbat nikah massal. Dengan demikian, terselenggaranya isbat nikah massal telah membantu terpenuhinya hak memperoleh identitas hukum berupa akta nikah bagi masyarakat yang tidak mampu dan perkawinan tersebut menjadi memiliki kekuatan hukum tetap.

Perlu diketahui bahwa berperkara di Pengadilan Agama dalam prakteknya ada dua alternatif yakni, bersifat permohonan dan bersifat gugatan. Yang dimaksud dengan permohonan adalah suatu permohonan yang di dalamnya berisi tuntutan hak perdata oleh satu pihak yang di dalamnya tidak mengandung sengketa. Sementara yang bersifat gugatan adalah suatu surat yang diajukan oleh penggugat kepada ketua pengadilan agama yang berwenang yang memuat suatu tuntutan yang mengandung sengketa.19 Prosedur pengajuan isbat nikah massal oleh MWC NU Kec. Gapura sama seperti pengajuan yang dilakukan di pengadilan agama seperti biasanya, hanya saja untuk isbat nikah massal ini dikoordinir oleh panitia pelaksana dan dilakukan di luar kantor pengadilan agama.

18 Fithratul Qayyimah, Wawancara, 29 Maret 2019.

19Mukti Arto, Praktek Perkara Perdata Pada Pengadilan Agama (Yogyakarta: Pustaka Pelajar, 1996), 39. 
Produk hukum perkara isbat nikah dapat berupa penetapan dan juga dapat berupa putusan. Jika isbat nikah diajukan oleh suami istri, maka permohonan bersifat voluntair dan produk hukumnya berupa penetapan. Selanjutnya, jika isi penetapan tersebut menolak permohonan isbat nikah, maka pihak suami dan istri bersama-sama atau suami atau istri masing-masing dapat mengupayakan kasasi. Tetapi, jika yang mengajukan permohonan isbat nikah adalah satu pihak (suami atau istri), maka permohonan bersifat kontensius dengan mendudukkan suami atau istri yang tidak mengajukan permohonan sebagai pihak termohon sehingga produk hukum yang dihasilkan berupa putusan dan terhadap putusan tersebut dapat diupayakan banding atau kasasi.20

Demikian halnya, jika termohon adalah suami yang masih terikat dengan perkawinan istri terdahulu, maka istri terdahulu juga harus dilibatkan dalam perkara. Jika tidak, maka permohonannya tidak akan diterima. Berbeda halnya, jika yang mengajukan adalah anak atau wali nikah atau yang berkepentingan dengan perkawinan tersebut, maka perkara ini harus dimasukkan perkara kontensius yang menjadikan suami, istri serta ahli waris lain sebagai termohon dalam perkara. 21

Suami atau istri yang telah ditinggal mati oleh istri atau suaminya, dapat mengajukan permohonan isbat nikah secara kontensius dengan mendudukkan ahli waris lainnya sebagai pihak termohon, produknya berupa putusan dan atas putusan tersebut dapat diupayakan banding dan kasasi. Berbeda halnya, suami atau istri yang ditinggal mati tidak mengetahui ada ahli waris lain selain dirinya, maka permohonan isbat nikah diajukan secara voluntair, produknya berupa penetapan. Apabila permohonannya ditolak maka pemohon dapat mengajukan upaya hukum kasasi.22

Kegiatan isbat nikah massal ini, masa persidangannya dilakukan dalam satu kali sidang, sehingga pada hari itu juga kegiatan langsung

20 Ita Musarrofa, Pencatatan Perkawinan di Indonesia (Surabaya: Uinsa Press, 2014), 151-152.

21 Ibid.

22Mahkamah Agung RI Dirjend Badan Peradilan Agama, Buku II, Pedoman Pelaksanaan Tugas dan Administrasi Peradilan Agama, (Jakarta: Edisi Revisi 2013), 155. 
selesai dan para peserta isbat nikah massal langsung bisa mendapatkan penetapan isbat nikah secara sah di mata hukum nasional. Adapun untuk persidangannya para hakim langsung mendatangi aula MWC NU Kecamatan Gapura dengan dihadiri 5 orang hakim dari pengadilan agama. Sidang pun langsung dilaksanakan secara bergantian. Adapun tahapan proses persidangan yang dilakukan, sama seperti sidang-sidang biasanya di pengadilan agama yaitu ada pemeriksaan identitas, pertanyaan-pertanyaan dari hakim, pembuktian, kemudian penetapan. Untuk pembuktian sendiri para peserta diberikan kesempatan untuk membuktikan surat berupa foto kopi kartu tanda penduduk kedua pihak dan foto kopi kartu keluarga.23

Selanjutnya, setelah pembuktian dianggap sempurna dan dinyatakan benar adanya perkawinan tersebut, peserta akhirnya mengikuti isbat nikah massal ini, kemudian dilakukan pembacaan penetapan isbat nikah massal. Setelah pembacaan penetapan oleh hakim, maka hakim mengeluarkan penetapan yang ditembuskan ke KUA.

Menurut Irsyad (42 Tahun) warga Gapura Tengah salah satu peserta isbat nikah massal ini, ia mengatakan, bahwa pelaksanaan kegiatan isbat nikah massal yang diselenggrakan oleh MWC NU Kecamatan Gapura ini, bekerjasama dengan Pemkab Sumenep bidang Hukum merupakan program yang luar biasa bagi dirinya dan masyarakat pada umumnya. Menurutnya, program semacam ini benar-benar kabar yang sangat menggembirakan untuk masyarakat kelas ekonomi rendah, karena sangat bermanfaat dan membantu mereka. Apalagi, bagi masyarakat yang awam tentang pentingnya pencatatan perkawinan melalui kegiatan isbat nikah massal tersebut.24

Adapun data peserta isbat nikah massal dengan pasangan masing-masing mencapai 160 pasangan. Berikut data peserta isbat nikah massal program MWC NU Kec. Gapura Kab. Sumenep:

\begin{tabular}{|c|c|c|c|c|}
\hline NO & NAMA SUAMI & NAMA ISTERI & $\begin{array}{c}\text { TAHUN } \\
\text { MENIKAH }\end{array}$ & $\begin{array}{c}\text { DIAQADKAN } \\
\text { OLEH }\end{array}$ \\
\hline
\end{tabular}

23Fithratul Qayyimah, Wawancara, 01 April 2019. 24Irsyad, Wawancara, 2 April 2019. 
Muh. Fathoni Hasyim: Implementasi Itsbat Nikah Massal......

\begin{tabular}{|c|c|c|c|c|}
\hline 1 & Muki & Atwani & 16-08-1997 & KH. Makki \\
\hline 2 & Asymawi & Sulthaniyah & 09-03-1981 & KH.Hesamuddin \\
\hline 3 & Abd. Lathif & Hamimah & 06-01-1986 & KH.Halim \\
\hline 4 & Rofiqi & Idawati & 15-10-1999 & K.Mursyid \\
\hline 5 & Yazid & Rumyani & 15-04-1998 & H.Hamdi \\
\hline 6 & Masduqi & Puzainah & $17-08-1996$ & K.Suhaili \\
\hline 7 & Asnawi & Siti Romlah & 22-01-1999 & KH.Mukafi \\
\hline 8 & Zaini & Misnatun & $29-12-1993$ & K. Sya'rani \\
\hline 9 & Masdawi & Arifah & 17-07-1999 & KH. Suhaili \\
\hline 10 & Tawil & Hawiya & 05-01-1993 & K. Hasyim \\
\hline 11 & M. Sholeh & Masidah & 12-06-1996 & KH. Mukafi \\
\hline 12 & Sugianto & Ely Fatmawati & 02-08-1995 & K. Hasyim \\
\hline 13 & Sahari & Arifah & 13-03-1995 & KH.Mukafi \\
\hline 14 & Sahri & Jum'ani & 12-08-1992 & H.Halim \\
\hline 15 & Saipun Nasir & Namiyah & 05-01-1996 & KH. Habibullah \\
\hline 16 & Sugiono & Hafidah & 22-05-1999 & H. Rahnawi \\
\hline 17 & Musamman & Fathimah & 09-01-1988 & KH. Zubairi \\
\hline 18 & Tawakkul & Juma'esah & 20-07-1989 & K.Dumyati \\
\hline 19 & Mattoni & Maniya B. Inah & 26-06-1994 & Ustaz Asik \\
\hline 20 & Moh. Idris & Zainab & 17-11-1992 & H. Zaini \\
\hline 21 & Maswi & Nima & 02-06-1996 & KH. Afifuddin \\
\hline 22 & Farid & Marmiya & $15-10-1997$ & KH. Imam Dasuki \\
\hline 23 & Sutipno & Daima & 28-10-1996 & KH. Masuri \\
\hline 24 & Tohayu & Hana & 01-07-1996 & KH. Afif Makruf \\
\hline 25 & Zaini & $\begin{array}{l}\text { Damma. B. } \\
\text { Muslima }\end{array}$ & 01-05-1971 & Masdawi \\
\hline 26 & Gani Andhika & Juwani & 04-04 & K. Ramsi \\
\hline 27 & Artawi & Azzani & 20-11-1988 & H. Zaini \\
\hline 28 & Sahrawi & Puwani & 05-07-1999 & H. Ilyas \\
\hline 29 & Thahir & Sintin & 16-08-1990 & K. Suni \\
\hline 30 & Markawi & Raudah & 01-07-1995 & KH. Aqil \\
\hline 31 & Marzuqi & Syarifa & 01-06-1997 & K. Sihabuddin \\
\hline
\end{tabular}


Muh. Fathoni Hasyim: Implementasi Itsbat Nikah Massal......

\begin{tabular}{|c|c|c|c|c|}
\hline 32 & Massuri & Tuniya & 11-11-1991 & KH. Zaini Fadli \\
\hline 33 & Muhammat & Juhriya & 06-08-1996 & K. Ahmat \\
\hline 34 & Saluki & Irawati & 05-07-1990 & KH. Fadlun \\
\hline 35 & Sahawi & Satima & 06-08-1996 & H. Ainun Najib \\
\hline 36 & Mattaher & Masniatun & 08-09-1996 & KH. Ainun Najib \\
\hline 37 & $\begin{array}{l}\text { Moh. Miski Al } \\
\text { Anshari }\end{array}$ & Siti Kamila & 03-05-1996 & K. Rusdi \\
\hline 38 & Murawi & Masrifah & & KH. Fadlun \\
\hline 39 & Barmawi & Amaniyah & 03-10-1991 & KH. Ramsi \\
\hline 40 & Sahruwi & Nawara & 17-08-1996 & H. Umar \\
\hline 41 & Ahmad Yono & Masniya & 05-05-1999 & KH. Afif Makruf \\
\hline 42 & Asmuni & Manisa & 17-08-1995 & H. Munir \\
\hline 43 & Abdullah Anas & Ainur Rifdah & 04-05-2000 & Abd. Adzim \\
\hline 44 & Arnawi Dura & Mas'odah & 13-01-1994 & K. Basi \\
\hline 45 & Ari Buddin & Masiyani Enni & 21-03-1990 & P. Mulahmi \\
\hline 46 & Robby & Sutiyana & 06-10-1999 & KH. Asy'ari \\
\hline 47 & Rusni & Mairi & 10-03-1980 & KH. Makki \\
\hline 48 & Amir & Rusfaidah & 06-11-1998 & KH. Zarkasih \\
\hline 49 & Rayyis & Rahema & 02-07-1998 & KH. Hanif \\
\hline 50 & Ah. Badri & Zaida & 20-09-2000 & KH. Hafidz \\
\hline 51 & Sa'ad & Aini & 05-06-1983 & KH. Hafidz \\
\hline 52 & Irsyad & Hosniyah & 25-11-1998 & KH. Hafidz \\
\hline 53 & Armawi & Satima & 01-10-1996 & K. Yunus \\
\hline 54 & Fathur Rohman & Hossida & 16-03-1999 & KH. Zanuji Fadlal \\
\hline 55 & Sukri & Salamah & $17-07-1975$ & KH. Umar \\
\hline 56 & Hosen & Rahmah & $12-12-1997$ & KH. Dumyati \\
\hline 57 & Saleh & Puhami & 15-08-1999 & KH. Dumyati \\
\hline 58 & H. Syamsul & Khairiyah & 04-08-1993 & KH. Hasan \\
\hline 59 & Mastuni & Maimunah & $10-2-2000$ & KH. Musthofa \\
\hline 60 & Sahlan & Sa'odah & 05-01-1982 & KH. Bisri \\
\hline 61 & Sahrawi & Siti Maryam & 09-02-1981 & K. Kafrawi \\
\hline 62 & Moh Dafi'e & Rahwiyah & & K. M. Damsid \\
\hline
\end{tabular}


Muh. Fathoni Hasyim: Implementasi Itsbat Nikah Massal......

\begin{tabular}{|c|c|c|c|c|}
\hline 63 & Darsono & Masrima & $12-12-1996$ & K. Musahwan \\
\hline 64 & Abu Ahmad & Muslimah & $15-05-2000$ & \\
\hline 65 & Satrawi & Rukiya & $10-12-1979$ & KH. Idris \\
\hline 66 & Duni & Arifah & 20-01-1993 & KH. Damsid \\
\hline 67 & Asyhari & Nur Imama & 20-08-1993 & KH. Warits Ilyas \\
\hline 68 & Masyono & Purani & 1996 & K. Abd Gaib \\
\hline 69 & M. Zaini & Rusmaida & $11-12-1998$ & KH. Imam Khozid \\
\hline 70 & Sumasnan & Hosmawati & 01-01-1996 & K. Ali Wafa \\
\hline 71 & Sumawi & Bunia & 09-10-1999 & H. Affanoridha \\
\hline 72 & Moh. Husain & Maniya & 11-08-1986 & H. Ridhawi \\
\hline 73 & Hariyanto & Maniya & $10-08-2000$ & H. Affanoridha \\
\hline 74 & Pukasman & Mariya & 19-09-1997 & H. Mathalil \\
\hline 75 & Ibnu Hajar & Sitti Mariyam & $12-08-1997$ & KH. Imam Khozid \\
\hline 76 & Jumad Riyadi & Astiyani & 07-08-1997 & KH. Khalil \\
\hline 77 & Zainal & Hosmawati & $30-09-1997$ & KH. Syarbini Latif \\
\hline 78 & Markip & Sumina & 01-07-1967 & K. Erru \\
\hline 79 & Buhari & Marsu'iya & 24-06-1965 & K. Erru \\
\hline 80 & Suyono & Amseya & 09-11-1959 & KH. Saleh \\
\hline 81 & Masnin & Isa & 21-07-1987 & K. Munawar \\
\hline 82 & Abu Hasan & Ruhma & 02-11-1986 & K. Muni \\
\hline 83 & Marsuki & Nurhayati & 01-08-1999 & K. Addus \\
\hline 84 & Samsul & Hosaima & $10-07-1992$ & K. Tayyib \\
\hline 85 & Rikso & Sawiye & $17-11-1997$ & K. Alawi \\
\hline 86 & Jumak & Suha & 17-06-1985 & K. Atem \\
\hline 87 & Saleh & Hasia & 01-10-1996 & K. Zubairi \\
\hline 88 & Hariyanto & Zairiyah & 21-09-1992 & KH. Mas'ud \\
\hline 89 & Titi Sutiyono & Sumairiya & 20-09-1999 & KH. Abd Asis \\
\hline 90 & Abd Fata & Siti Afiyah & 05-08-1998 & KH. Ahmad \\
\hline 91 & Sundari & Misnaya & 02-10-1995 & KH. Hafid Mustofa \\
\hline 92 & Abdus Sholeh & Faridatul Hilmiya & 20-05-1997 & KH. Abd Rahman \\
\hline 93 & Saturi & Sa'ima & $15-08-1992$ & Sa'id \\
\hline
\end{tabular}


Muh. Fathoni Hasyim: Implementasi Itsbat Nikah Massal......

\begin{tabular}{|c|c|c|c|c|}
\hline 94 & Nihawi & Buhari & $30-07-1996$ & KH. Dulmajit \\
\hline 95 & Ibno & Masduya & 10-09-1997 & KH. Amir \\
\hline 96 & Razak & Arminatun & 02-07-1994 & KH. Arifin \\
\hline 97 & M. Thayyib & Busami & 09-05-1998 & K. Arifin \\
\hline 98 & Thairi & Kholifah & 03-12-1997 & KH. Mas'od Bunyani \\
\hline 99 & Zainul Fatah & Salma & 20-04-1995 & KH. Mas'od Bunyani \\
\hline 100 & Santari & Tola'ima & 02-11-1999 & KH. Abd Aziz \\
\hline 101 & Bhusawa & Maryani & 01-02-1989 & KH. Dulmajit \\
\hline 102 & Hasan Basri & Sumina & 10-02-1997 & KH. Basit \\
\hline 103 & Samat & Samawiya & $17-10-1976$ & K. Yunus \\
\hline 104 & Armawi & Masriyah & 20-11-1990 & KH. Basit \\
\hline 105 & Syamsuni & Misnaya & 03-10-1990 & K. Razak \\
\hline 106 & Saduri & Hosmah & 1988 & K. Hatim \\
\hline 107 & Nihrawi & Juma'isa & $30-06-1990$ & K. Hatim \\
\hline 108 & Suparman & Rustini & 1998 & K. Alawi \\
\hline 109 & Yusri & Asiya & 23-11-1995 & KH. Jazuli \\
\hline 110 & Asnan Efendi & Misnati & 01-09-1996 & K. Hatim \\
\hline 111 & Rusdi & Nawiya & 08-02-1996 & KH. Jazuli \\
\hline 112 & Abu Yanto & Nurhasanah & $17-12-1999$ & KH. Jazuli \\
\hline 113 & Abu Sanah & Aisyah & 08-12-1992 & KH. Qasim \\
\hline 114 & Mathari & Ruhaniya & 20-11-1991 & K. Hatim \\
\hline 115 & Sunarwi & Ahma & 25-07-1989 & Sutomo \\
\hline 116 & Sahwini & Puima & 17-05-1996 & K. Mas'od \\
\hline 117 & Rasyidi & Mayani & 15-07-1999 & KH. Mas'od \\
\hline 118 & Sito & Hosmah & 14-07-1991 & KH. Qasim \\
\hline 119 & Sahab & Adna & 15-07-1995 & KH. Qasim \\
\hline 120 & Sahlan & Sahnati & $10-11-1986$ & KH. Qasim \\
\hline 121 & Atmawi & Zahna & 06-09-1988 & KH. Qasim \\
\hline 122 & Su'adi & Wami & 1994 & \\
\hline 123 & Sahir & Sihma & 1999 & KH. Mas'od \\
\hline 124 & Abd. Shomad & Zaidah & 07-09-1990 & KH. Qasim \\
\hline
\end{tabular}


Muh. Fathoni Hasyim: Implementasi Itsbat Nikah Massal......

\begin{tabular}{|c|c|c|c|c|}
\hline 125 & Rawi & Sawiya & 10-11-1996 & KH. Mas'od \\
\hline 126 & M. Alwi & Satmawiyah & $12-05-1968$ & K. Hatim \\
\hline 127 & M. Sahwi & Asiya & $10-11-1971$ & K. Hatim \\
\hline 128 & Murahwi & Misna & 1999 & KH. Mas'od \\
\hline 129 & Miskali & Ma'ina & 02-09-1997 & KH. Mas'od \\
\hline 130 & K. Sadik & Maiya & 01-01-1980 & K. Siheb \\
\hline 131 & Fahroly Darwis & Asnaini & 20-08-1982 & Abd Aziz \\
\hline 132 & Dasuki & Astima & 15-04-1994 & KH. Yasin \\
\hline 133 & H. Helmi Amin & Muzayyadah & 01-01-1999 & K. Zeinuddin \\
\hline 134 & H. Ali Makki & Hafiyah & $15-05-1998$ & K. Qasim \\
\hline 135 & Rahwini & Rihwani & 20-11-1997 & K. Ahmad \\
\hline 136 & Moh. Saleh Kadi & Hadima & 1978 & Sutomo \\
\hline 137 & Samawi & Misnawati & 1988 & H. Sahe \\
\hline 138 & Muhammad Nur & Salwiyah & 1973 & Ni'am \\
\hline 139 & Atmawi & Sumiati & 06-02-1977 & K. Rasidi \\
\hline 140 & Asan & Sahriyah & 12-03- 1996 & H. As'adi \\
\hline 141 & Munahwi & Sahrami & 02-08-1987 & K. Asrama \\
\hline 142 & Jatim & Sagiya & 06-07-1984 & KH. Fathor Rahman \\
\hline 143 & Alwi & Saniya & 03-05-1990 & K. Ali Bahar \\
\hline 144 & Moh. Nikmat & Rohaniya & 26-10-1990 & K. Mas'od \\
\hline 145 & Abdurrahman & St. Fatimah & 14-01-1999 & \\
\hline 146 & Sumar & Budiya & 11-02-1992 & K. Nawawi \\
\hline 147 & Sattar & Rahmawati & 05-01-1982 & K. Nawawi \\
\hline 148 & Najiburrohman & Sananti & $10-10-1997$ & K. Mas'od \\
\hline 149 & Osman Riyadi & Niyati & $26-11-2000$ & K. Mas'od \\
\hline 150 & Ahmad & Juma'ati & 15-11-1999 & K. Mas'od \\
\hline 151 & Ahmad Mufi & Mizani & & \\
\hline 152 & Musaddi & Tunniya & 16-07-1995 & K. Arif \\
\hline 153 & Toyo & Suhna & 30-07-1995 & KH. Bushrawi \\
\hline 154 & Ahmawi & Tuyani & 10-07-1998 & KH. Bushrawi \\
\hline 155 & Sahnan & Awiya & 07-06-1996 & KH. Bushrawi \\
\hline
\end{tabular}


Muh. Fathoni Hasyim: Implementasi Itsbat Nikah Massal......

\begin{tabular}{|l|l|l|l|l|}
156 & Hasan & Marwa & $20-05-1980$ & KH. Bushrawi \\
\hline 157 & Atmo & Zaina & $27-10-1975$ & KH. Bushrawi \\
\hline 158 & Marsuki & Sa'dani & & KH. Bushrawi \\
\hline 159 & Atrayu & Masrifah & $15-04-1975$ & K. Nadar \\
\hline 160 & Abd Rasyid & Mas'odah & $10-11-1993$ & KH. A. Zubairi \\
\hline
\end{tabular}

Sumber: Diolah dari Panitia Isbat Nikah Massal MWC NU Kecamatan Gapura Kabupaten Sumenep.

Majelis Wakil Cabang Nahdlatul Ulama Kecamatan Gapura mengadakan program isbat nikah massal bermaksud untuk menjaga eksistensinya sebagai organisasi masyarakat keagamaan yang mampu berkontribusi dalam mengadvokasi masyarakat di Kecamatan Gapura Kabupaten Sumenep. Program isbat nikah massal dapat membantu masyarakat yang perkawinannya masih tidak diakui oleh negara karena belum tercatat di KUA.

Dengan demikian, secara umum program isbat nikah massal ini memberikan manfaat secara langsung kepada masyarakat berupa: Pertama, legalitas status perkawinan yang diakui negara. Kedua, dapat memperjelas status perkawinan. Ketiga, dapat melindungi keluarga terhadap ketidak jelasan identitas. Keempat, dapat memberikan kepastian hukum terhadap hak-hak diantara suami atau isteri. Kelima, dapat melindungi keluarga apabila terjadi sengketa waris. Keenam, dapat melindungi kedua belah pihak dalam hal perceraian.25

Secara kelembagaan organisasi masyarakat, kegiatan isbat nikah massal ini juga memberikan dampak positif kepada organisasi MWC NU Kecamatan Gapura Kabupaten Sumenep. Dampak positif tersebut di antaranya adalah: Pertama, eksistensi MWC NU Kecamatan Gapura Kabupaten Sumenep dalam mengadvokasi masyarakat memberikan tanggapan positif dari masyarakat. Kedua, program isbat nikah massal memberikan solusi alternatif kepada masyarakat dalam rangka meningkatkan kesadaran tentang pentingnya pencatatan dalam perkawinan. Ketiga, MWC NU sebagai ormas kultural yang dekat dengan masyarakat mampu berkontribusi

25Irsyad, Wawancara, 2 April 2019. Bandingkan dengan artikel Nastangin, Tinjauan Filosofis (Pasal 2 ayat 2) Undang-Undang Perkawinan No 1 Tahun 1974 tentang Pencatatan Perkawinan, Mahakim, Vol. 2 No. 1 (Januari 2018), 19. 
untuk memfasilitasi kebutuhan masyarakat demi terwujudnya masyarakat yang tertib hukum.26

\section{Tinjauan Sosiologis-Filosofis Implementasi Isbat Nikah Massal}

Dalam ketentuan peraturan perundang-undangan dan Kompilasi Hukum Islam (KHI) khususnya pasal 7 disebutkan bahwa suatu perkawinan hanya dapat dibuktikan dengan akta nikah. Oleh sebab itu, perkawinan yang tidak mendapatkan akta nikah sebab belum dicatatkan di lembaga yang berwenang dalam hal ini adalah Kantor Urusan Agama (KUA), maka dapat melakukan pengajuan isbat nikah. Dalam konteks ini, sejatinya, pemohon isbat nikah bertujuan agar legalitas perkawinanya dapat diakui dengan mendapatkan bukti otentik berupa kutipan akta nikah.

Pengadilan agama yang memiliki kewenangan dalam menetapkan permohonan isbat nikah dapat memberikan kepastian hukum kepada masyarakat yang telah melakukan akad perkawinan tetapi belum dicatatkan secara legal. Oleh karena itu, fungsi hukum dalam perkara isbat nikah adalah mengatur dan memberi perlindungan atas hak-hak masyarakat dalam rangka mewujudkan ketertiban dalam administrasi pencatatan perkawinan. Isbat nikah dalam konteks ini dapat memberikan perlindungan terhadap hakhak perdata kepada para pihak yang terikat dalam akad perkawinan. 27

Secara sosiologis, sebab utama banyaknya perkawinan yang dilakukan tanpa pencatatan di Kantor Urusan Agama adalah praktik nikah siri yang masih tinggi di masyarakat Madura. Secara kultur sosial keagamaan yang selama ini berkembang dan sudah mengakar di tengah-tengah masyarakat. Bagi masyarakat Madura nikah siri bukan merupakan hal yang tabu untuk dilakukan, karena secara legalitas fikih yang mereka yakini, bahwa pernikahan yang sudah terpenuhi syarat-rukunnya sudah sah menurut hukum agama.

26Fithratul Qayyimah, Wawancara,1 April 2019.

27Mohammad Ali Fikri, “Analisis Sosiologi Hukum Islam Terhadap Pelaksanaan Isbat Nikah oleh Pengadilan Agama, Shakhsiyah Burhaniyab: Jurnal Penelitian Hukum Islam, Vol. 01 No. 01, (Januari 2016), 25 
Bagi masyarakat Madura, nikah siri yang diakadkan oleh Kiai tertentu adalah salah satu bentuk keberkahan yang menjadi pendorong dan motivasi dalam melakukan akad perkawianan tanpa dicatatkan di Kantor Urusan Agama. Hal itu, karena secara yuridis formal, dalam Undang-Undang No 1/1974 dan Kompilasi Hukum Islam (KHI) tidak ada larangan secara jelas dalam praktik akad nikah siri tersebut.28 Sebaliknya, Kompilasi Hukum Islam sendiri justru membuka peluang untuk dilakukan isbat nikah bagi perkawinan siri. Hal itu membuktikan bahwa nikah siri yang mentradisi di masyarakat mendapatkan justifikasi meskipun tidak secara langsung.29

Dalam konteks ini, sejatinya masyarakat Madura yang telah melakukan akad perkawinan tanpa dicatatkan dan dilakukan dengan akad nikah siri tersebut, merupakan fenomena sosial eksis yang memiliki fungsi sosial positif. Dalam analisis perspektif struktural fungsional dijelaskan, bahwa jika suatu fenomena sosial tersebut mempunyai fungsi positif (fungsional) dalam masyarakat, dengan kata lain fenomena sosial itu eksis karena ia berfungsi bagi sistem sosial budaya dimana ia berada. Dari sini, nikah siri tetap eksis karena dalam ruang sosial memiliki fungsi dalam bentuk integrasi sosial legal-unlegitimate, sehingga ada pihak-pihak yang melanggengkan nikah siri itu sendiri.30

Selain itu, ada kebutuhan-kebutuhan pokok yang tidak terpenuhi dalam lembaga formal. Parsons dengan sistem nilai, norma roles, dan status mengungkapkan bahwa perilaku nikah siri

28Larangan nikah siri dipahami dari Pasal 2 UU No 1 Tahun 1974 dan Kompilasi Hukum Islam Pasal 5 yang mengatur tentang pencatatan perkawinan. Tujuan pencacatan menurut KHI adalah agar terjamin ketertiban perkawinan bagi masyarakat Islam setiap perkawinan harus dicatat. Pencatatan tersebut dilakukan oleh Pegawai Pencatat Nikah sebagaimana yang diatur dalam UU No 22 tahun 1946 jo UU No. 32 Tahun 1954 tentang Penetapan Berlakunya Undang-Undang Republik Indonesia Tanggal 21 Nopember 1946 No.22 Tahun 1946 tentang Pencatatan Nikah, Talak dan Rujuk di Seluruh Daerah Luar Jawa dan Madura. 29Aidil Alfin dan Busyro, "Nikah Siri dalam Tinjauan Hukum Teoretis dan Sosisologi Hukum Islam Indonesia", Al-Manahij: Jurnal kajian Hukum Islam, Vol. XI No. 1 (Juni 2017), 73.

30Thiwaty Arsah, dkk.," Nikah Siri di Warurejo dalam Perspektif Sejarah", Paramita, Vol. 25, No. 2 (2015), 213 
yang dilakukan individu ditentukan oleh struktur untuk mempertahankan sistem dimana struktur itu menentukan perilaku individu. Motif pernikahan yang berbeda ini oleh Weber dimaknai sebagai tindakan rasional dan irrasional. Artinya, pernikahan siri yang terjadi di masyarakat karena ada pengaruh tradisi dan budaya. Pernikahan selanjutnya lebih didasarkan pada tindakan rasional yang penuh arti subyektitif dari aktor pelaku nikah siri.31

Pada tataran ini, perkawinan siri yang dilakukan oleh masyarakat Madura, khususnya di Kecamatan Gapura Kabupaten Sumenep juga dipengaruhi oleh kebijakan perangkat desa setempat. Pemerintah desa setempat memiliki peran signifikan dalam mendorong maraknya pernikahan siri, karena setiap pernikahan siri dapat dicatatkan pada pemerintah desa dengan membayar biaya yang lebih ringan daripada dicatatkan pada Kantor Urusan Agama.

Oleh karena itu, isbat nikah sebagai alternatif dalam melegalkan perkawinan siri yang terjadi di masyarakat di satu sisi memberikan kepastian hukum menurut hukum positif dan dapat menjamin hakhak pihak yang terikat dalam akad perkawinan. Akan tetapi, di sisi yang lain, adanya isbat nikah justru akan melanggengkan tradisi nikah siri yang sejatinya kontra produktif dengan semangat untuk mengatur dan menertibkan administrasi perkawinan itu sendiri.32

Selanjutnya, secara filosofis hakikat eksistensi suatu hukum dengan segala dinamikanya merupakan kehendak hati nurani manusia yang mengharapkan kehidupan yang aman, tentram, damai, sejahtera dan merasakan keadilan.33 Dalam konteks ini, isbat nikah massal yang diinisiasi oleh MWC Nahdlatul Ulama Kecamatan

31Ibid.

${ }_{32} \mathrm{Upaya}$ untuk mengurangi tingkat pernikahan siri masih banyak mengalami kendala. Salah satunya, karena sebagian masyarakat Muslim masih banyak berpegang teguh kepada perspektif fikih tradisonal. Dalam fikih tradisional perkawinan sudah dianggap sah apabila ketentuan-ketenuan yang menjadi syarat dan rukunnya pernikahan telah terpenuhi. Pencatatan perkawinan dianggap sebagai penghambat dalam proses pernikahan itu sendiri. Karena pencatatan perkawinan hanya bersifat administratif, sehingga tidak mempengarui legalitas (sah-tidaknya) pernikahan. Lihat, Zulfan, "Fenomena Nikah Siri di Indonesia dari Aspek Sosiologi Hukum dan kaitannya dengan Legislasi Pencatatan Perkawinan", Fitrah, Vol. 08, No. 2 (Juli-Desember 2014), 296.

33Irfan Helmi Juni, Filsafat Hukum (Bandung: Pustaka Setia, 2012), 5. 
Gapura Kabupaten Sumenep dalam rangka untuk merealisasikan keadilan dengan memberikan hak-hak para pihak yang terikat dalam perkawinan. Jika terjadi perselisihan di antara para pihak yang berakad dalam perkawinan, maka dapat melakukan upaya hukum untuk mengajukan gugatan karena akta perkawinan merupakan bukti otentik.

Dengan demikian, secara ontologis, adanya peraturan perundang-undangan tentang pencatatan perkawinan yang tertuang dalam UU No 1 Tahun 1974 tentang perkawianan dalam Pasal 2 ayat 2 memberikan pengaruh bagi masyarakat dalam memfasilitasi realitas empirik di tengah-tengah masyarakat. Dasar pijakan keharusan adanya pencatatan dalam setiap perkawinan yang tertuang dalam UU dan Kompilasi Hukum Islam adalah aspek kemaslahatan, keadilan dan perlindungan terhadap hak-hak setiap orang serta sebagai tindakan preventif dalam mencegah kemadharatan.

Aturan tentang pencatatan pernikahan dapat dilihat dalam UU No. 22/1946. Undang-Undang ini mengatur hanya administrasi perkawinan dan menegaskan bahwa pernikahan diawasi oleh pegawai pencatat nikah. Aturan pencatatan pernikahan diperkuat dalam UU No. 1 Tahun 1974 dan Kompilasi Hukum Islam serta secara teknis diatur dalam peraturan terbaru yaitu PMA No 20 Tahun 2019. KHI menyatakan bahwa perkawinan dinyatakan sah dengan hadirnya pencatat pernikahan yang resmi atau jika didaftarkan. Tidak dipenuhinya pendaftaran perkawinan berakibat tidak absahnya perkawinan dan upaya hukum di Pengadilan akan ditolak, jika perkawinan tidak terdaftar. Dalam konteks inilah, isbat nikah sebagai solusi alternatif agar legalitas perkawinannya dapat diakui sesuai hukum positif yang berlaku.

Secara epistemologis, dasar hukum isbat nikah adalah bersumber dari Kompilasi Hukum Islam. KHI juga memberikan rumusan tentang perkawinan yang sah dan ketentuan untuk tertibnya perkawinan. Pasal 4 Kompilasi Hukum Islam memberikan penegasan bahwa "perkawinan adalah sah apabila dilakukan menurut hukum Islam sesuai dengan pasal 2 ayat 1 UU no 1 tahun1974 tentang perkawinan. Pasal 5 KHI merumuskan: (1) agar terjamin ketertiban perkawinan bagi masyarakat Islam setiap perkawinan harus dicatat; (2) pencatatan perkawinan tersebut pada 
ayat (1), dilakukan oleh Pegawai Pencatat Nikah sebagaimana yang diatur dalam Undang-undang No. 22 Tahun 1946 jo Undangundang No. 32 Tahun 1954 dan secara teknis dalam PMA Nomor 20 Tahun 2019.

Seperti yang juga dijelaskan dalam PMA Nomor 20 Tahun 2019 dalam pasal 2 (1) disebutkan bahwa pernikahan seorang laki-laki dan perempuan beragama Islam dicatat dalam Akta Nikah, sedangkan (2) Pencatatan Pernikahan dalam Akta Nikah dilakukan oleh Kepala KUA Kecamatan atau PPN LN34.

Dalam konteks hukum Islam, isbat nikah didukung oleh dalil qiyas awlawi terhadap transaksi muamalah lainnya. QS. Al-Baqarah [2]: 282 menjelaskan bahwa akad atau transaksi muamalah yang dilakukan non-tunai (utang) maka ada keharusan untuk dilakukan pencatatan. Oleh karena itu, jika transaksi muamalah saja harus dicatat, apalagi akad perkawinan sebagai ikatan yang kuat dan suci (mitsaqan ghalidah) lebih urgen dan niscaya. Selain itu, dari aspek maslahah al-mursalah juga menguatkan pentingnya pencatatan nikah, sehingga isbat nikah merupakan keniscayaan untuk melindungi hakhak pihak yang berakad nikah.

Sementara secara aksiologis, pasal 2 ayat 2 undang-undang perkawinan tentang Pencatatan Perkawinan merupakan suatu hal yang urgent, bahkan menjadi sebuah persyaratan administratif yang harus dilakukan. Tujuannya adalah agar perkawinan itu jelas dan menjadi bukti bahwa perkawinan itu telah terjadi, baik bagi yang bersangkutan, keluarga kedua belah pihak, orang lain, maupun bagi masyarakat karena peristiwa perkawinan itu dapat dibaca dalam suatu surat yang bersifat resmi dan dalam suatu daftar yang sengaja dipersiapkan untuk itu, sehingga sewaktu-waktu dapat digunakan, terutama sebagai alat bukti tertulis yang otentik.35

Dengan demikian, isbat nikah adalah cara yang dapat ditempuh oleh pasangan suami istri yang telah menikah secara sah menurut hukum agama untuk mendapatkan pengakuan dari negara atas pernikahan yang telah dilangsungkan oleh keduanya beserta anak-

34 PMA No 20 Tahun 2019 Pasal 1

35Kamal Muchtar, "Nikah Siri Di Indonesia”, Jurnal Al Jami ab No. 56 (1994), 145-155. 
anak yang lahir selama pernikahan, sehingga pernikahannya tersebut berkekuatan hukum.

\section{Penutup}

Dari uraian di atas dapat disimpulkan bahwa setting sosial masyarakat Madura masih banyak melakukan pernikahan siri sehingga status pernikahannya belum dicatatkan di Kantor Urusan Agama (KUA). Dalam merespon hal itu, MWC Nahdlatul Ulama Kecamatan Gapura Kabupaten Sumenep menggagas program isbat nikah massal bekerjasama dengan bidang Hukum Pemerintah Kabupaten Sumenep. Implementasi Isbat nikah massal dilaksanakan di aula MWC NU Kec. Gapura Kab. Sumenep, menghadirkan 5 (lima) hakim dari Pengadilan Agama Sumenep, dengan proses persidangan sebagaimana mestinya.

Secara sosiologis, perkawinan siri yang dilakukan oleh masyarakat Madura, khususnya di Kecamatan Gapura Kabupaten Sumenep dipengaruhi oleh kebijakan perangkat desa setempat. Pemerintah desa setempat memiliki peran signifikan dalam mendorong maraknya pernikahan siri, karena setiap pernikahan siri dapat dicatatkan pada pemerintah desa dengan membayar biaya yang lebih ringan daripada dicatatkan pada Kantor Urusan Agama. Dalam konteks ini, maka MWC NU sebagai ormas keagamaan berkepentingan untuk memfasilitasi masyarakat untuk melakukan isbat nikah massal agar mendapatkan kepastian hukum dan legalitas atas perkawinannya.

Secara filosofis, isbat nikah massal yang diinisiasi oleh MWC Nahdlatul Ulama Kecamatan Gapura Kabupaten Sumenep dalam rangka untuk merealisasikan keadilan dengan memberikan hak-hak para pihak yang terikat dalam perkawinan. Jika terjadi perselisihan di antara para pihak yang berakad dalam perkawinan, maka dapat melakukan upaya hukum untuk mengajukan gugatan, karena akta perkawinan merupakan bukti otentik. Adapun dasar pijak tentang urgensi isbat nikah dalam hukum Islam adalah dalil qiyas awlawi terhadap transaksi muamalah lainnya dan kaidah maslabah mursalah. Sedangkan pijakan hukum positif tertuang dalam UU No. 1 Tahun 1974 dan Kompilasi Hukum Islam.] 


\section{Daftar Pustaka}

Ahmad Rofiq. Hukum Islam Di Indonesia. Jakarta: Raja Grafindo Persada, 1997.

Amir Nuruddin dan Azhari Akmal Tarigan. Hukum Perdata Islam Di Indonesia. Jakarta: Kencana Prenada Media Group, 2004.

Faizah Bafadhal. "Isbat Nikah dan Implikasinya Terhadap Status Perkawinan Menurut Peraturan Perundang-Undangan Indonesia". Jurnal Ilmu Hukum. Maret 2014.

M. Khusnul. "Ratio Decidendi Penetapan pengesahan isbat nikah di pengadilan agama”, Yuridika, (Jurnal) Vol. 30, No.2, Mei 2015.

Riswan Munthe dan Sri Hidayani. "Kajian Yuridis Permohonan Itsbat Nikah Pada Pengadilan Agama Medan. Jurnal Pendidikan Ilmu-Imu Sosial. Vol. 9. No. 2. 2017.

Mieta Djohan OE.. "Isbat Nikah dalam Hukum Islam dan Perundang-Undangan di Indonesia. Jurnal Pranata Hukum. Vol. 8 No. 2 Juli 2013.

Ramdani Wahyu Sururie. "Polemik di Seputar Isbat Nikah dalam Sistem Hukum Perkawinan Indonesia. al-Manabij: Jurnal Kajian Hukum Islam. Vol. XI No. 2 Desember 2017.

Mohammad Rokib. "Penolakan Ithbat Nikah Siri Bagi Suami yang Sudah Beristri. Al-Hukama: The Indonesian Journal of Islamic Family Law. Vol. 06 No. 02. Desember 2016.

Taufiqurrahman, Islam dan Budaya Madura, (Makalah dipresentasikan pada forum Annual Conference on Contemporary Islamic Studies, Direktorat Pendidikan Tinggi Islam, Ditjen Pendidikan Islam, Departemen Agama RI, di Grand Hotel Lembang Bandung, 26-30 November 2006.

Latief A Wiyata. Madura yang Patub?: Kajian Antropologi Mengenai Budaya Madura. Jakarta: CERIC-FISIP UI, 2003.

Mukti Arto. Praktek Perkara Perdata Pada Pengadilan Agama. Yogyakarta: Pustaka Pelajar, 1996.

Ita Musarrofa. Pencatatan Perkawinan di Indonesia. Surabaya: Uinsa Press, 2014.

Mahkamah Agung RI Dirjend Badan Peradilan Agama, Buku II, Pedoman Pelaksanaan Tugas dan Administrasi Peradilan Agama. Jakarta: Edisi Revisi 2013.

Nastangin, Tinjauan Filosofis (Pasal 2 ayat 2) Undang-Undang Perkawinan No 1 Tahun 1974 tentang Pencatatan Perkawinan. Mahakim, (Jurnal),Vol. 2 No. 1. Januari 2018.

Mohammad Ali Fikri. "Analisis Sosiologi Hukum Islam Terhadap Pelaksanaan Isbat Nikah oleh Pengadilan Agama, Shakhsiyah Burhaniyah: Jurnal Penelitian Hukum Islam, Vol. 01 No. 01. Januari 2016.

Aidil Alfin dan Busyro, "Nikah Siri dalam Tinjauan Hukum Teoretis dan Sosisologi Hukum Islam Indonesia". Al-Manahij: Jurnal kajian Hukum Islam. Vol. XI No. 1 Juni 2017. 
Muh. Fathoni Hasyim: Implementasi Itsbat Nikah Massal......

Thiwaty Arsah dkk.," Nikah Siri di Warurejo dalam Perspektif Sejarah", Paramita, (Jurnal),Vol. 25, No. 2. 2015.

Zulfan, "Fenomena Nikah Siri di Indonesia dari Aspek Sosiologi Hukum dan kaitannya dengan Legislasi Pencatatan Perkawinan”. Fitrah, (Jurnal),Vol. 08, No. 2. Juli-Desember 2014.

Irfan Helmi Juni. Filsafat Hukum. Bandung: Pustaka Setia, 2012.

\section{Wawancara}

Khoiriyah, Wawancara, 29 Maret 2019.

Armiatun, Wawancara, 2 April 2019.

Masida, Wawancara, 2 April 2019.

Fithratul Qayyimah, Wawancara, 1 April 2019. 